\title{
Spatial patterning and occupation dynamics during the Early Holocene in an archaeological site from the south coast of Tierra del Fuego: Binushmuka I
}

\section{Patrones espaciales y dinámica de ocupación durante el Holoceno Temprano en un sitio arqueológico en la costa sur de Tierra del Fuego: Binushmuka I}

Atilio Francisco Zangrando ${ }^{1}$, Hein B. Bjerck ${ }^{2}$, Ernesto L. Piana ${ }^{3}$, Heidi M. Breivik ${ }^{4}$, Angélica M. Tivoli' and Joan Negre ${ }^{6}$

\begin{abstract}
We explore the implications of the spatial structure of the artifact assemblages at the Binushmuka I site, located in the north coast of the Beagle Channel (Tierra del Fuego). The information corresponding to the stratigraphy, chronology and composition of the archaeological assemblages of this site is described. We focus on the spatial distribution of artifacts, which mainly depend on the number and duration of the occupations and the size of the group, to evaluate the temporal structure of the assemblages. For assessing pattern mobility, we also consider the spatial consistency of the location of the site in relation to features of the paleogeography and the archaeological landscape.

The confined size of the assemblages $\left(-7-8 \mathrm{~m}^{2}\right)$ are likely to represent occupations by small sized groups. The spatial consistency between early Holocene occupations and marine hunter-gatherer assemblages observed at a regional level suggests that groups with similar mobility and foraging strategies could have occupied the site.
\end{abstract}

Keywords: coastal site, early Holocene, early coastal foragers, lithic technology, spatial analysis.

\section{Resumen}

En este trabajo analizamos la distribución espacial de conjuntos de artefactos líticos correspondientes a las ocupaciones del Holoceno Temprano del sitio Binushmuka I, costa norte del canal Beagle, Tierra del Fuego. Asimismo, exploramos la consistencia espacial de estas ocupaciones con la identificación de rasgos de la paleogeografía y del paisaje arqueológico. Sobre la base de este análisis, discutimos las implicaciones para la movilidad de grupos de cazadores-recolectores tempranos. Esta publicación constituye un primer informe de las excavaciones efectuadas hasta el momento en el sitio, por lo que se describe la información correspondiente a la estratigrafía, la cronología y la composición de los conjuntos arqueológicos.

El bajo grado de dispersión y disgregación espacial de los conjuntos $\left(-7-8 \mathrm{~m}^{2}\right)$ estarían indicando ocupaciones por grupos de reducido tamaño. Por último, señalamos la consistencia espacial entre las ocupaciones costeras del Holoceno Temprano con las correspondientes para cazadores-recolectores marinos del Holoceno Medio, lo cual permite plantear hipótesis sobre las pautas de movilidad de cazadores-recolectores tempranos en la región.

Palabras claves: sitio costero, Holoceno Temprano, cazadores-recolectores, tecnología lítica, análisis espacial.

Recibido: 28 noviembre 2016. Aceptado: 25 agosto 2017

1 Centro Austral de Investigaciones Científicas (CADIC - CONICET). Bernardo Houssay 200 (V9410CAB) Ushuaia, Tierra del Fuego, ARGENTINA. Email: panchozan@yahoo.com.ar; fzangrando@cadic-conicet. gob.ar

2 NTNU University Museum, Norwegian University of Science and Technology, 7493 Trondheim, NORWAY. Email: hein.bjerck@ntnu.no

3 Centro Austral de Investigaciones Científicas (CADIC - CONICET). Bernardo Houssay 200 (V9410CAB) Ushuaia, Tierra del Fuego, ARGENTINA. Email: arqueologiatierradelfuego@gmail.com

4 NTNU University Museum, Norwegian University of Science and Technology, 7493 Trondheim, NORWAY. Email: heidi.breivik@ntnu.no

5 Centro Austral de Investigaciones Científicas (CADIC - CONICET). Bernardo Houssay 200 (V9410CAB) Ushuaia, Tierra del Fuego, ARGENTINA. Email: amtivoli@gmail.com

6 Laboratori d'Arqueologia Quantitativa, Departament de Prehistòria, Universitat Autònoma de Barcelona, Bellaterra (Cerdanyola del Vallès), 08193 Barcelona, SPAIN. Email: negreperez@gmail.com 


\section{Introduction}

The use of littoral environments by forager populations can be traced back to the early Holocene in the north coast of the Beagle Channel (Orquera \& Piana, 2009; Zangrando, 2009; Piana, Zangrando \& Orquera, 2012). The factors that motivated these early coastal foragers to inhabit that southern region is a question of constraints in the marine environment and the different kinds of resources that it provides (Piana et al., 2012; Bjerck \& Breivik, 2012; Bjerck \& Zangrando, 2013). "Early Coastal Foragers" (ECF) (Bjerck, Zangrando, Breivik, Piana \& Negre, 2016b) have engaged a prominent part of our research agenda, which looks to understand human adaptation to the sea in the southern tip of South America (Piana et al., 2012). This research is stimulating and presents at the same time some methodological challenges.

No shell midden formation is known previous to $6400 \mathrm{BP}$ in the north coast of the Beagle Channel (Orquera \& Piana 2009). Early occupations in the archaeological sequence of that region are characterized by very poor preservation of organic material, which creates difficulty in the exploration of strategies of animal resource procurement. A few pinniped bones were recovered at the First Component of Túnel I (6900 BP; 7600-7900 cal. BP) (Orquera \& Piana, 1999: 48), and very fragmented and calcined bones in the layer $S$ of Imiwaia I (7800 BP; 8400-8700 cal. BP). The implications of this scarce record are still under discussion due to aspects of taphonomy and sample size. Although further studies are still required, the majority of interpretations about these early foragers in the Beagle Channel emphasize the technology and typology of lithic assemblages (Orquera \& Piana, 1999: 48; Orquera \& Piana, 2009; Piana et al., 2012). Those studies have pinpointed that artifacts do not show morphological similarities with later nor earlier assemblages in Tierra del Fuego. However, it can be questioned whether typological approaches to lithic assemblages are appropriate to highlight settlement dynamics, in terms of coast-inland mobility.

Coastal settlement patterns of hunter-gatherer and fisher societies can be diverse, as they depend on environmental opportunities and constraints, technology and social organization (e.g. Yesner, 1980; Erlandson, 2001; Bailey \& Milner, 2002). Thus, coastal sites are palimpsest deposits that can indicate diverse social dynamics with the maritime environment for long periods of time in the same region. Although definitions based on habitats, technology and percentage of marine diet (e.g. Yesner, 1980; Lyman, 1991) tend to rely on criteria that are hard to identify in the archaeological record (Erlandson, 1991), there is a matter of scale concerning the use of maritime environments by hunter-gatherer societies (Bjerck, 2009). For example, requirements of technology, landscape knowledge and social organization between gathering of shellfish on the coastline and development of foraging activities in the sea are significantly different. Important differences are also expected in settlement patterns and site locations. As we have recently reported (Bjerck \& Zangrando, 2016), marine hunter-gatherers need to develop activities at land bases, and land bases are in turn normally concentrated at secure landing places (e.g., natural harbours), those settlements are likely to be aggregated at specific locations near the coastline (Bjerck, 1990, 2017). Terrestrial societies with different mobility and foraging strategies do not face these constraints along mainland coastal environments, and will probably apply different settlement patterns in the landscape (Ames 2002). How are we to identify and differentiate these patterns in the archaeological landscape? Our approach here is to explore the long-term trajectory of site use. The repetitive patterns expressed in the form of durable remains and features can be assessed to provide information about the human relationship with maritime environments. In this sense, when redundancy over time in the spatial structure of the site is observed (spatial consistency), we might expect that its location provides particular material conditions that, due to mobility strategies, prove to be attractive dwelling places.

Binushmuka I was excavated as part of an extensive and systematic survey for recording the location of archaeological sites at Cambaceres Bay, with a special focus on ECF settlements (Bjerck et al., 2016b). This paper explores the implications of spatial structure on the artifact assemblages at this site, and of its spatial consistency in terms of land use by ECF in 
southern coastal Tierra del Fuego. We assume here that the spatial distribution of artifacts and features in relation to the paleogeographic location and the archaeological landscape can be used to evaluate the temporal characteristics of the assemblage (Bailey, 2008; Clark, 2016; Breivik, Bjerck, Zangrando \& Piana, 2016). First, the site location and its relation to the paleogeography reconstructed for Cambaceres Bay is presented. Second, the stratigraphy and chronological information are described. Finally, the spatial analyses of the lithic assemblages are developed, and their implications for the land use strategies of hunter-gatherer in the early Holocene are assessed.

\section{Site location and paleogeography}

Binushmuka is located in a semi-enclosed part of the Cambaceres Bay that provides very good shelter for human settlement and aquatic mobility, especially because it is protected from the Westerlies.

Cambaceres Bay and its environs are located within a drumlin field assigned to the Last Glacial Maximum (Rabassa, Heusser \& Rutter, 1990). This drumlin field covers an area of $100 \mathrm{~km}^{2}$ and presents a maximum W-E length of $20 \mathrm{~km}$. The coastal zone of the study area contains many other landforms, i.e., marine terraces and littoral gravel ridges (Figure 1).

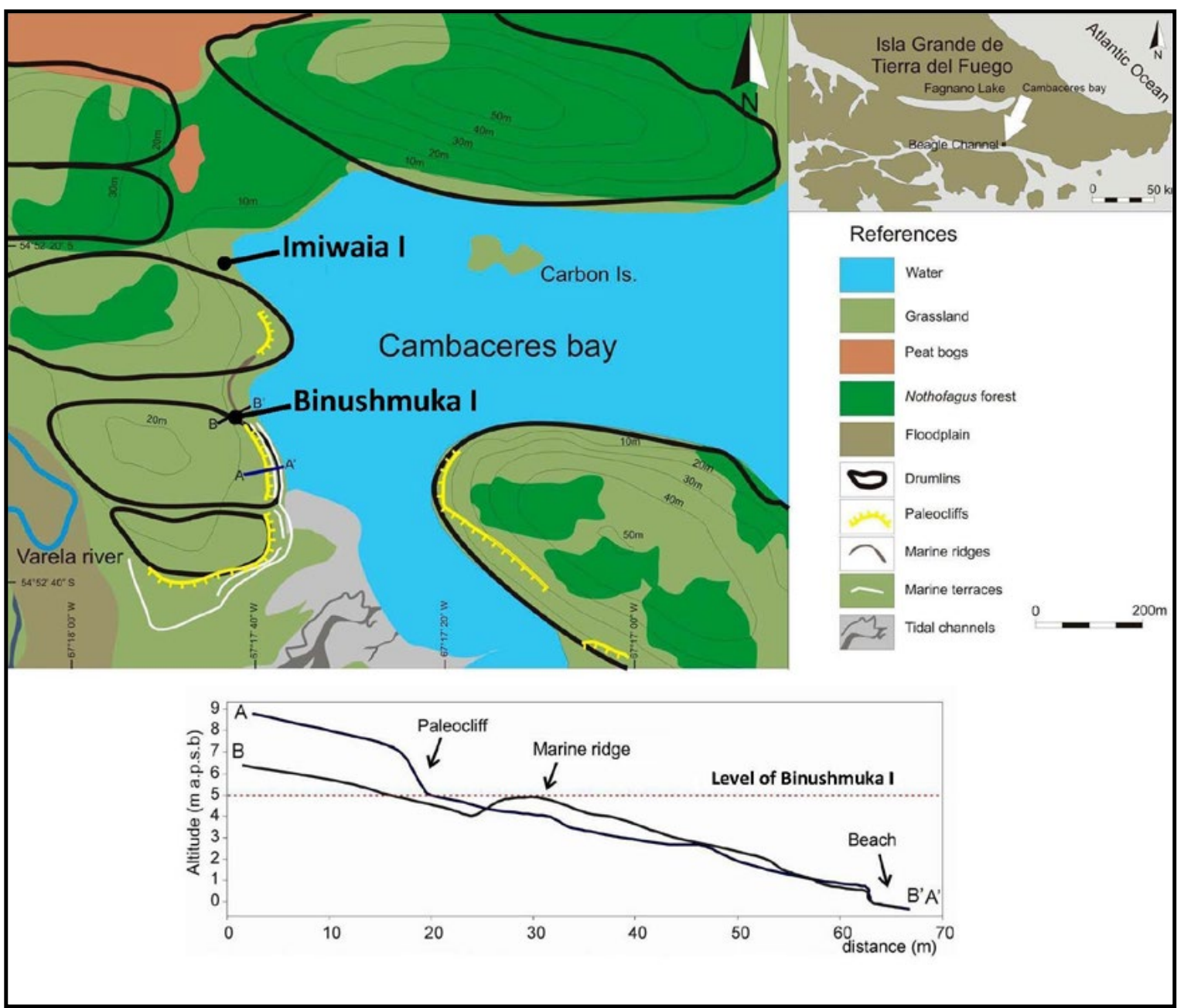

Figure 1. Geomorphologic map and topographic profiles showing marine landforms in Cambaceres Bay, and locations of Binushmuka I and Imiwaia I sites. The altitude on the vertical axis of the figure below is measured in meters above present storm berm (m a.p.s.b.). Modified figure from Zangrando et al. (2016). 
The distribution of these landforms and the associated marine deposits is constrained by drumlin field morphology. Between these promontories there are former and present beaches associated with inter-drumlin depressions (Zangrando et al., 2016).

Binushmuka I site is in the western coast of the bay at approximately $5.5 \mathrm{~m}$ a.s.l, just behind a littoral gravel ridge (Figures 1 and 2). Coastal landforms in the Cambaceres Bay perimeter indicate that the sea level reached $5 \mathrm{~m}$ a.s.l. during the middle Holocene (Zangrando et al., 2016). Geomorphological and chronological data also indicate the formation of coastal landforms during the Holocene transgression maximum in this area of the Beagle Channel. Thus, the local marine conditions during the occupations at the Binushmuka I site were different than today. A quite larger land extension has been suggested for the early Holocene (Bujalesky, 2011) and the coast line level would have been slightly different around 8000 years ago with a lower sea level. Around 6000 BP, the Paleo-bay Cambaceres had an open configuration that would have allowed greater influence of waves and currents, and better oxygenation of the waters than today (Figure 3).

\section{Excavation, stratigraphy and chronology}

Excavations at the site were conducted over two seasons between 2012 and 2013 and covered an area of $48.25 \mathrm{~m}^{2}$. After a testing phase, excavations occurred in two large areas. The main excavation (A)

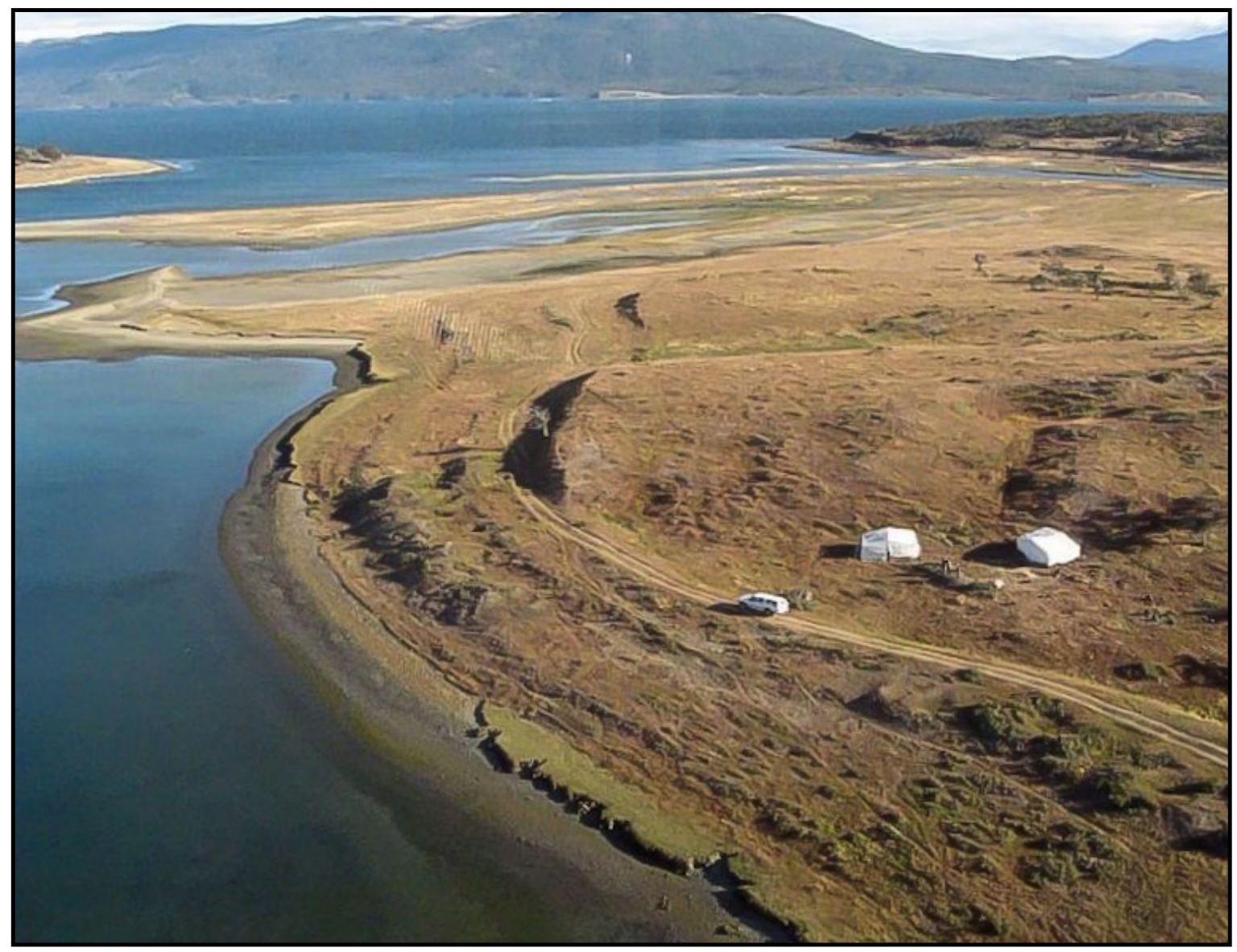

Figure 2. Aerial photograph taken from the north. The white tents point the location of Binushmuka I. In the background, the picture shows the mouth of the Varela River followed by the Beagle Channel and finally Navarino Island (Chile). The road and pickup truck indicate the position of the marine ridge, which ends in the paleo-cliffs pronounced by shadows. 

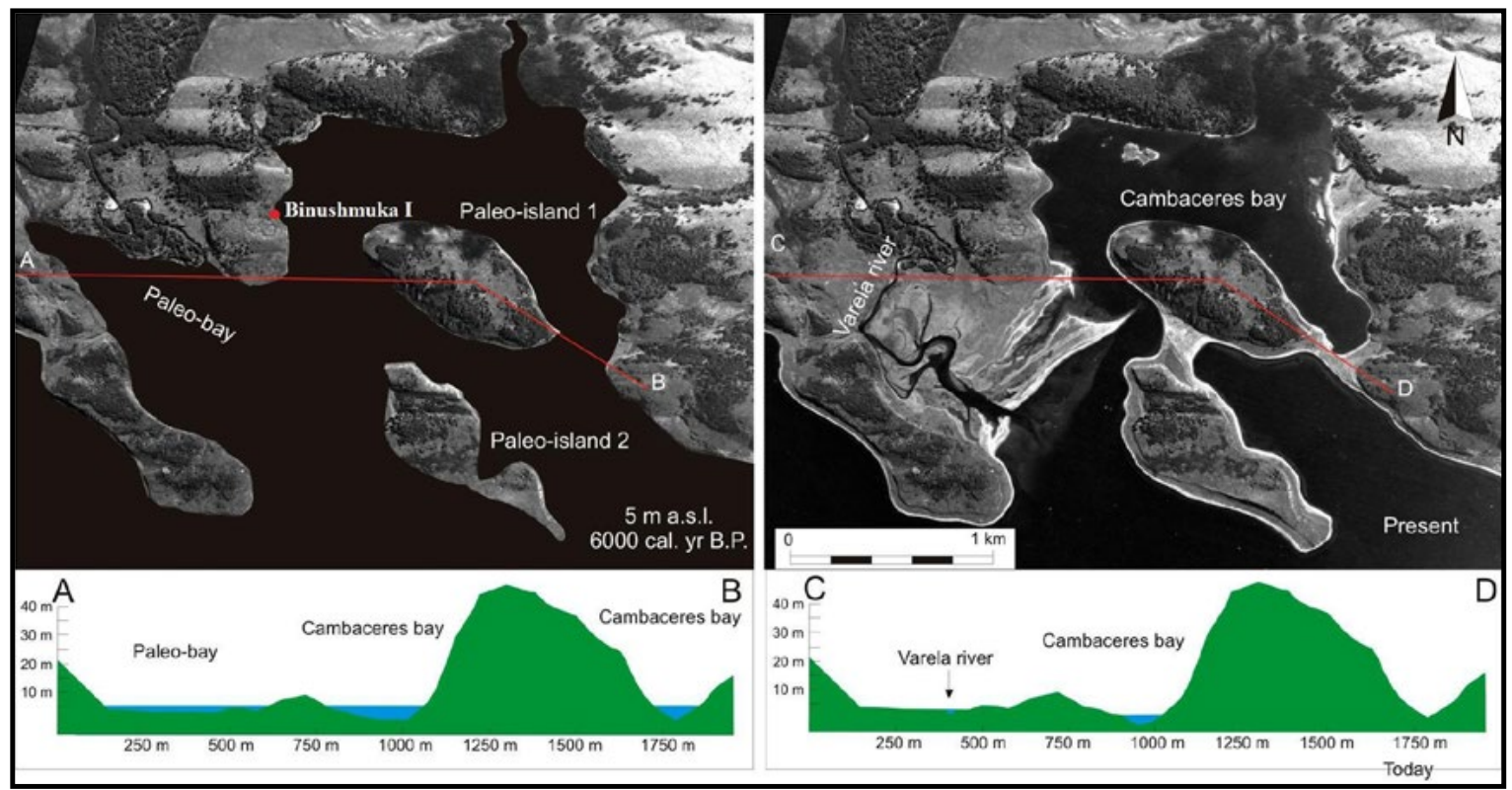

Figure 3. Palaeogeographical model of Cambaceres Bay based on Global Mapper 10 (www.globalmapper.com) and Shuttle Radar Topography Mission (SRTM) programs (Farr et al., 2007). Note the position of Binushmuka I in a small paleo-bay between two paleo-cliffs; good natural place for landing, and protected from the Westerlies. Modified figure from Zangrando et al. (2016). Letters A, B, C and D indicate the extreme points of the profiles in the aerial photography and in the paleogeographic model of the Cambaceres Bay.

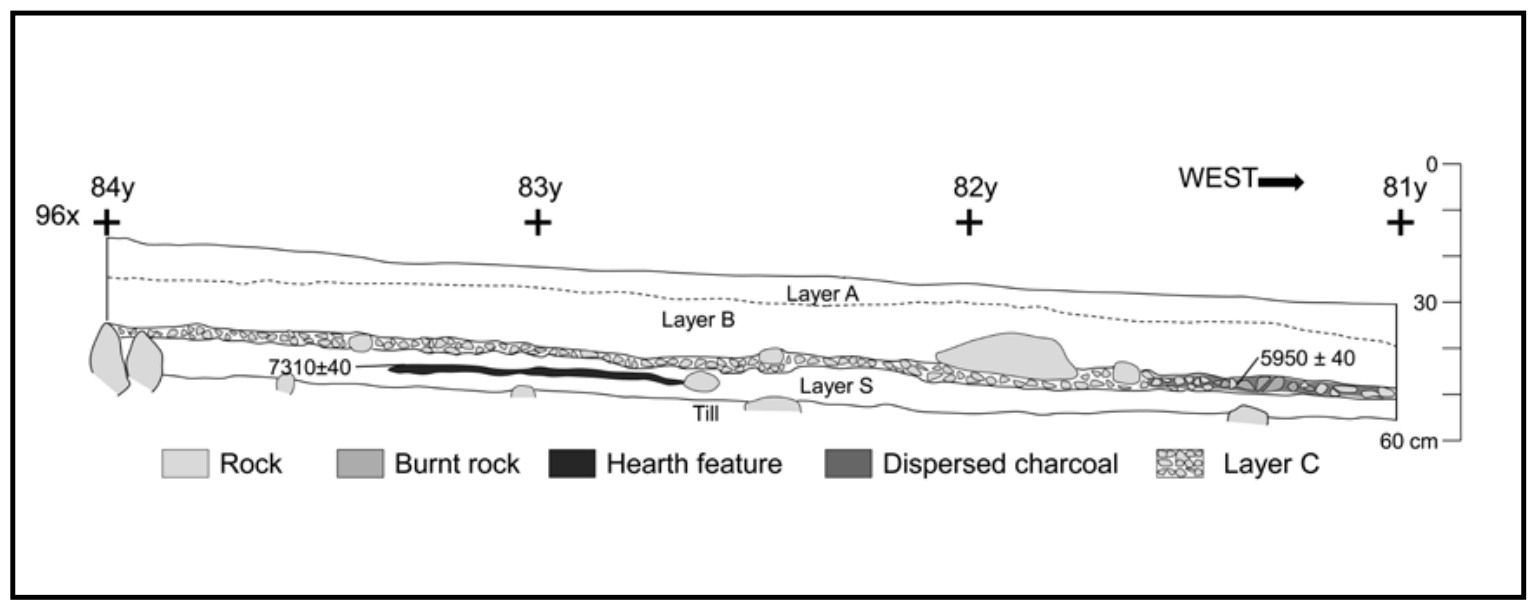

Figure 4. Section of the Binushmuka deposits (drawn by H. Bjerck and A.F. Zangrando).

included $24 \mathrm{~m}^{2}$ and produced 1497 artifacts. The other excavated area is located fifteen meters to the south-west (B), which covered a surface of $16 \mathrm{~m}^{2}$ and produced 8794 artifacts. Between both excavations, 314 artifacts were documented from 33 test-pits of $0.5 \times 0.5 \mathrm{~m}\left(8.25 \mathrm{~m}^{2}\right)$.
Binushmuka I comprises four stratigraphical units with different sediment matrices and anthropogenic inclusions (Figure 4). The different layers show different times of occupation and different frequencies of artifacts (Tables 1 and 2). 
Table 1. Chronological data from Binushmuka 1 (*burnt root).

Radiocarbon data was calibrated using SHCal04 curve (McCormac et al., 2004) from Calib Rev 6.0.1 program.

\begin{tabular}{|c|c|c|c|c|c|c|}
\hline Source & $\begin{array}{c}\text { Stratigraphic } \\
\text { layer }\end{array}$ & ${ }^{14} \mathrm{C} \mathrm{BP}$ & Cal 2 o BP & $\delta 13 \mathrm{C}$ & Material & Lab code \\
\hline Area $A^{*}$ & $\mathrm{~B} / \mathrm{C}$ & $1890 \pm 30$ & $1696-1869$ & -21.2 & Charcoal & Beta347690 \\
\hline Area A & $\mathrm{C}$ & $1963 \pm 38$ & $1729-1934$ & -24.2 & Charcoal & AA99090 \\
\hline Area A & $S$ & $7486 \pm 64$ & $8155-8386$ & -24.9 & Charcoal & AA99092 \\
\hline Area B & $\mathrm{C}$ & $5902 \pm 45$ & $6527-6754$ & -24.6 & Charcoal & AA99089 \\
\hline Area B & $\mathrm{C}$ & $5950 \pm 40$ & $6627-6804$ & -24.2 & Charcoal & Beta347692 \\
\hline Area B & $S$ & $7310 \pm 40$ & $7980-8170$ & -24.2 & Charcoal & Beta347691 \\
\hline Test-pit (108x-84y) & $\mathrm{B} / \mathrm{C}$ & $1884 \pm 40$ & $1691-1872$ & -24.4 & Charcoal & AA99093 \\
\hline Test-pit (108x-84y) & $\mathrm{C}$ & $1929 \pm 39$ & $1709-1898$ & -25.0 & Charcoal & AA99091 \\
\hline
\end{tabular}

Table 2. Frequencies of lithic categories by different excavated areas and layers from Binushmuka I.

\begin{tabular}{|l|r|r|r|r|r|r|r|r|r|}
\hline Categories & \multicolumn{3}{|c|}{ Area A } & \multicolumn{3}{c|}{ Area B } & \multicolumn{3}{c|}{ Test-pits } \\
\hline Layers & B & C & S & B & C & S & B & C & S \\
\hline Tools & 7 & 54 & 7 & 0 & 31 & 5 & 0 & 20 & 0 \\
\hline Blanks & 0 & 0 & 0 & 0 & 0 & 5 & 0 & 0 & 0 \\
\hline Cores & 1 & 11 & 3 & 0 & 8 & 2 & 0 & 8 & 0 \\
\hline Flakes & 31 & 338 & 580 & 6 & 679 & 360 & 0 & 423 & 0 \\
\hline Microflakes & 20 & 250 & 169 & 0 & 486 & 7028 & 0 & 267 & 4 \\
\hline Other debitage & 2 & 9 & 33 & 0 & 9 & 0 & 0 & 71 & 0 \\
\hline Total & $\mathbf{6 1}$ & $\mathbf{6 6 2}$ & $\mathbf{7 9 2}$ & $\mathbf{6}$ & $\mathbf{1 2 1 3}$ & $\mathbf{7 4 0 0}$ & $\mathbf{0}$ & $\mathbf{7 8 9}$ & $\mathbf{4}$ \\
\hline
\end{tabular}

Layer $S$ is situated on top of the till formations (drumlins), and it shows a dominance of silt fraction, probably of aeolian origin. This layer presents the highest frequency of artifacts $(\mathrm{N}=8197)$, which is mainly concentrated in Area B. Test pits showed no continuity between the artifact assemblages from the two excavated areas. A hearth feature appeared in Area B, but there is still no convincing evidence to suggest the presence of wall remnants, prepared floors, post molds or other distinct architectural features in the excavations; probably the excavated area is not big enough to detect these types of features. No bone material was recorded. The hearth feature located in Area B was radiocarbon dated to -7300 BP ( -8000 cal. BP, Figure 4$)$. Another radiocarbon date from a charcoal concentration associated with a lithic assemblage from Area A offered a date of -7500 BP ( -8300 cal. BP) (Table 1$)$.

Layer C is a gravel-dominated lithological unit which covers layer $S$. Fewer artifacts were recorded in this stratum $(\mathrm{N}=2664)$, but with more ubiquity throughout the site. Of particular interest is the presence of artifacts $(\mathrm{N}=146)$ of exotic raw materials (green obsidian), including tools, flakes and microflakes. The fact that the source of this stone appears to be near the Brunswick Peninsula (Chile) suggests that hunter-gatherers with maritime mobility produced this assemblage; this has interesting implications to be revisited later in the discussion. The excavation of layer $\mathrm{C}$ did not provide evidence of features of space organization (e.g. post molds 
or hearths) in Area A. Conversely, a grouping of burned rocks and fire-cracked stones with abundant charcoal were observed in Area B (Figure 4). $A$ radiocarbon analysis on charcoal samples from this feature provided a date of $\sim 5950 \mathrm{BP}(-6700$ cal. BP). During excavation of layer $C$, in the south quadrants of Area $\mathrm{A}$, evidence of removed sediment was observed: a heterogeneous matrix with organic content appeared mixed with large rocks at different levels of the stratigraphy. Patches of gravel were also seen at different depths. These disturbances may be related to natural tree-falls.

Different radiocarbon dates on charcoal samples from the base to the top of the layer $\mathrm{C}$ offered distinctive results around $6000 \mathrm{BP}$ for Area B, and around $1800 \mathrm{BP}$ for Area A and test pits (Table 1). While in Area $B$ the radiocarbon information was obtained from the feature indicated above, dis- persed charcoal was dated from layer C in Area A. In addition, the excavation conducted at this area allowed to identify burnt roots going through from the layer B to the layer C. One burnt root sample was radiocarbon dated and provided a similar age to the dispersed charcoal $(-1800 \mathrm{BP}$, see Table 1$)$. Considering these results, and that no hearth features were recorded, it was not possible to assign a cultural origin to the charcoal collected and radiocarbon dated from layer $\mathrm{C}$ at the Area A.

Layer B is at the top of the archaeological sequence and corresponds to the organic horizon of the modern soil. It generated few artifacts $(\mathrm{N}=67)$, which were mainly recovered in Area A. Finally, on the top limit of the stratigraphy, the A horizon is characterized by a very high density of roots and grassy vegetation. No archaeological material was recovered in this stratum.

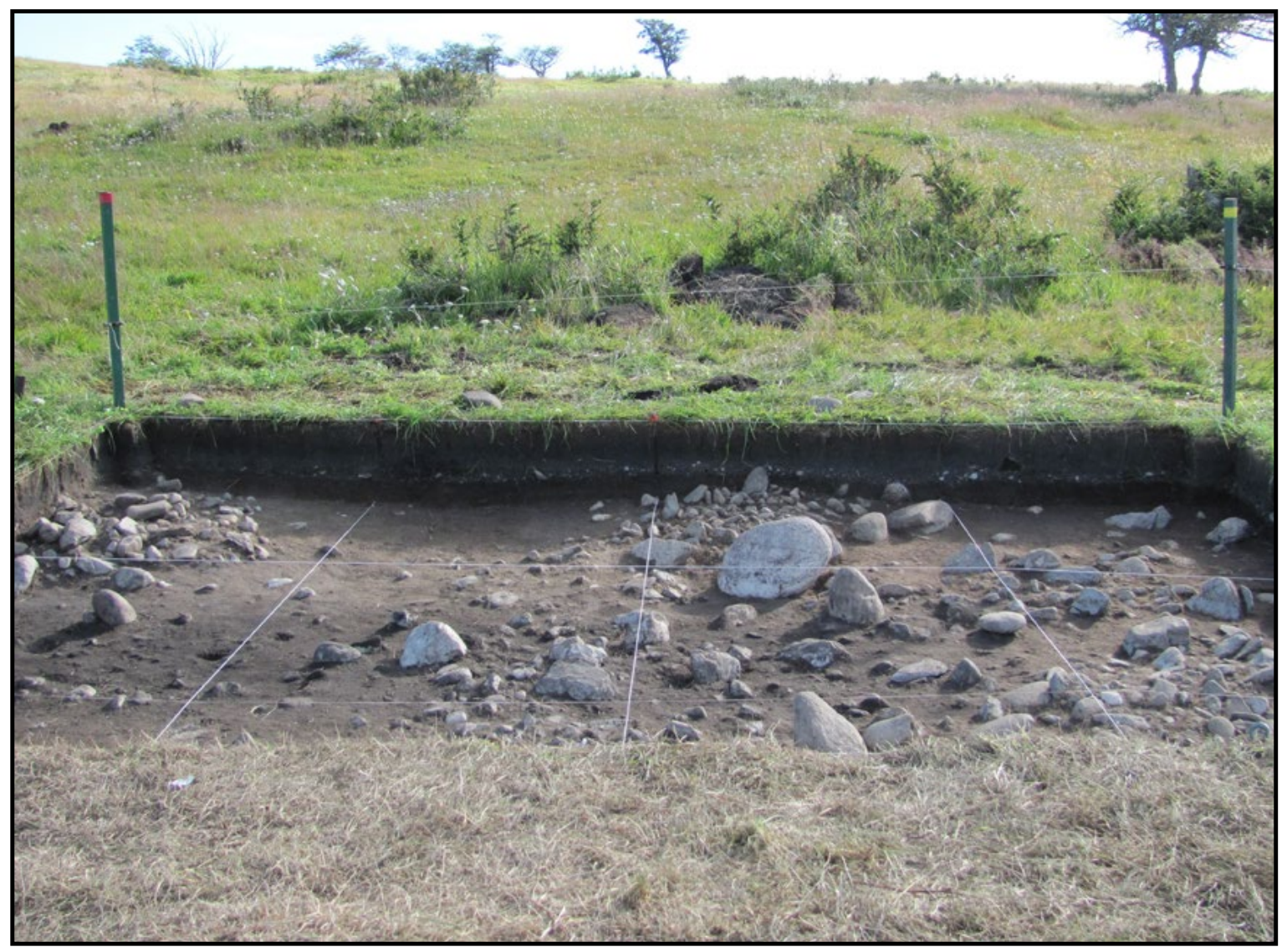

Figure 5. Excavation units $(1 \times 1 \mathrm{~m})$ in Area B. The picture shows the till outcropping in the excavated area, and over which layer $S$ was deposited. 
The lithic assemblages of Binushmuka site are shallowly buried, and occupations were encountered between 12 and $38 \mathrm{~cm}$ below the modern ground surface (Figures 4 and 5). To characterize the depositional environment of the site, it is important to consider that layers $\mathrm{A}$ and $\mathrm{B}$ are part of a soil-formation process. Layer $\mathrm{C}$ (gravel-dominated deposit) is an unconsolidated material underlying those organic horizons and are related to the formation of the coastal landform. The composition of the layer has relation to the sediment of the paleo-beach formed during the Holocene maximum transgression (Bjerck et al., 2016b); this maximum transgression is dated to circa 6000 years BP in the Beagle Channel region (Gordillo, Bujalesky, Pirazzoli, Rabassa \& Saliège, 1992; Grill et al., 2002; Isla \& Bujalesky, 2008; Rabassa, Heusser \& Stuckenrath, 1986; Rabassa, Coronato, Gordillo, Candel \& Martínez, 2009).

In summary, and concerning the site integrity, we observe that: a) Layer $S$ is clearly separated from layer $\mathrm{C}$ by an unconformity throughout the site; $\mathrm{b}$ )
The stratigraphic section that comprises to the layers $\mathrm{B}$ and $\mathrm{C}$ in Area $\mathrm{A}$ includes mixing materials, removal of sediments, and lacks reliable chronological determinations for the archaeological assemblages; and c) The stratigraphic sequence of Area $\mathrm{B}$ and the archaeological record of layer $\mathrm{C}$ seem to retain a higher degree of integrity.

\section{Assemblage structure and artifact density}

A recent analysis (Breivik et al., 2016) compared mobility patterns among marine foragers of the high-latitude seascapes of southern Tierra del Fuego and Norway by using parameters compiled by James Chatters (1987) from a range of anthropological and archaeological case studies. In this analysis accumulation of debris, accumulation of layers and discreteness of features were useful archaeological measures of mobility frequency and settlement patterns (Table 3).

Table 3. Suggested archeological measures and expectations on Mobility frequency as presented in Breivik et al., 2016. Adapted and compiled from James Chatters, 1987.

\begin{tabular}{|l|l|l|l|l|l|}
\hline \multirow{2}{*}{ Dimension } & Archaeological measures & \multicolumn{3}{|c|}{ Expectations } \\
\hline & & $\begin{array}{l}\text { Short term, } \\
\text { repeated } \\
\text { occupations: }\end{array}$ & $\begin{array}{l}\text { Short term, single } \\
\text { occupations: }\end{array}$ & $\begin{array}{l}\text { Long term, single } \\
\text { occupations: }\end{array}$ & $\begin{array}{l}\text { Long term, repeated } \\
\text { occupations: }\end{array}$ \\
\cline { 2 - 6 } & Accumulation of debris & $\begin{array}{l}\text { More debris, } \\
\text { diverse } \\
\text { accumulation }\end{array}$ & $\begin{array}{l}\text { Less debris, less } \\
\text { variety }\end{array}$ & $\begin{array}{l}\text { More debris, diverse } \\
\text { accumulation }\end{array}$ & $\begin{array}{l}\text { More debris, diverse } \\
\text { accumulation }\end{array}$ \\
\cline { 2 - 6 } & Accumulation of layers & $\begin{array}{l}\text { No cultural layers } \\
\text { / thin cultural } \\
\text { layers divided by } \\
\text { natural horizons }\end{array}$ & No cultural layer & Thick cultural layer & $\begin{array}{l}\text { Several cultural layers } \\
\text { divided by natural } \\
\text { horizons }\end{array}$ \\
\cline { 2 - 6 } & \multirow{2}{*}{ Discreteness of features } & $\begin{array}{l}\text { Features are } \\
\text { disrupted }\end{array}$ & $\begin{array}{l}\text { Discrete but } \\
\text { easily discerned } \\
\text { feature }\end{array}$ & $\begin{array}{l}\text { Features are disrupted } \\
\text { but highly visible }\end{array}$ & Features are disrupted \\
\hline
\end{tabular}

Different ethnoarchaeological studies also support the prediction that discarding of small materials is likely to occur in situ, while larger items are moved away from activity areas, since they hinder ongoing activities within a site (e.g., Binford, 1978, 1983; Brooks \& Yellen, 1987; Stevenson, 1991).
For O'Connell (1987), this causes a spatial sorting between items with different sizes, wherein larger materials tend to be more dispersed and smaller materials tend to remain near the place of primary deposition. Even without considering that dispersion of archaeological items can result from natural 
agents (e.g. colluvial processes, bioturbation or use of land surface by animals), it is normally assumed that the degree of size sorting is contingent on the duration of the occupation. The longer the stay of the group at a site, the greater and denser is the dispersion of obtrusive waste (O'Connell, 1987; Bartram, Kroll \& Bunn, 1991; Clark, 2016; Codding, Zeanah, Bliege Bird, Parker \& Bird, 2016). On the other hand, the amount of small material remaining in situ can vary depending on the efficiency of the cleaning technology (Hitchcock, 1987; O’Connell, 1987; Stevenson, 1991). In this sense, it is inferred that the increase in duration or number of occupations is correlated to the development level of size sorting processes and the size of the archaeological assemblage (Clark, 2016; Codding, Zeanah, Bliege Bird, Parker \& Bird, 2016).

The relationship between humans and the littoral environments can therefore be explored through the study of size sorting processes and the size of the archaeological assemblages. Importantly, the expectations derived from those ethnoarchaeological preconceptions depend on the extent to which such sorts of features persisted as visible traces between different occupations given the rate of sedimentation in palimpsests (Bailey \& Galanidou, 2009).

We examine the spatial distribution considering the artifact density of debitage differentiating microflakes (complete or fragmented flakes minor to $1 \mathrm{~cm}$ ) from flakes and other artifacts, and its potential relation to hearths or architectural features. Considering the information presented above about the archaeological integrity of the assemblages, this analysis is conducted for the lithic assemblages from layer C in Area B and from layer S of both areas. Table 2 shows the frequencies of the lithic assemblages by the main technological categories. While flakes and microflakes are dominant in all deposits, microflakes are particularly abundant in Area B.

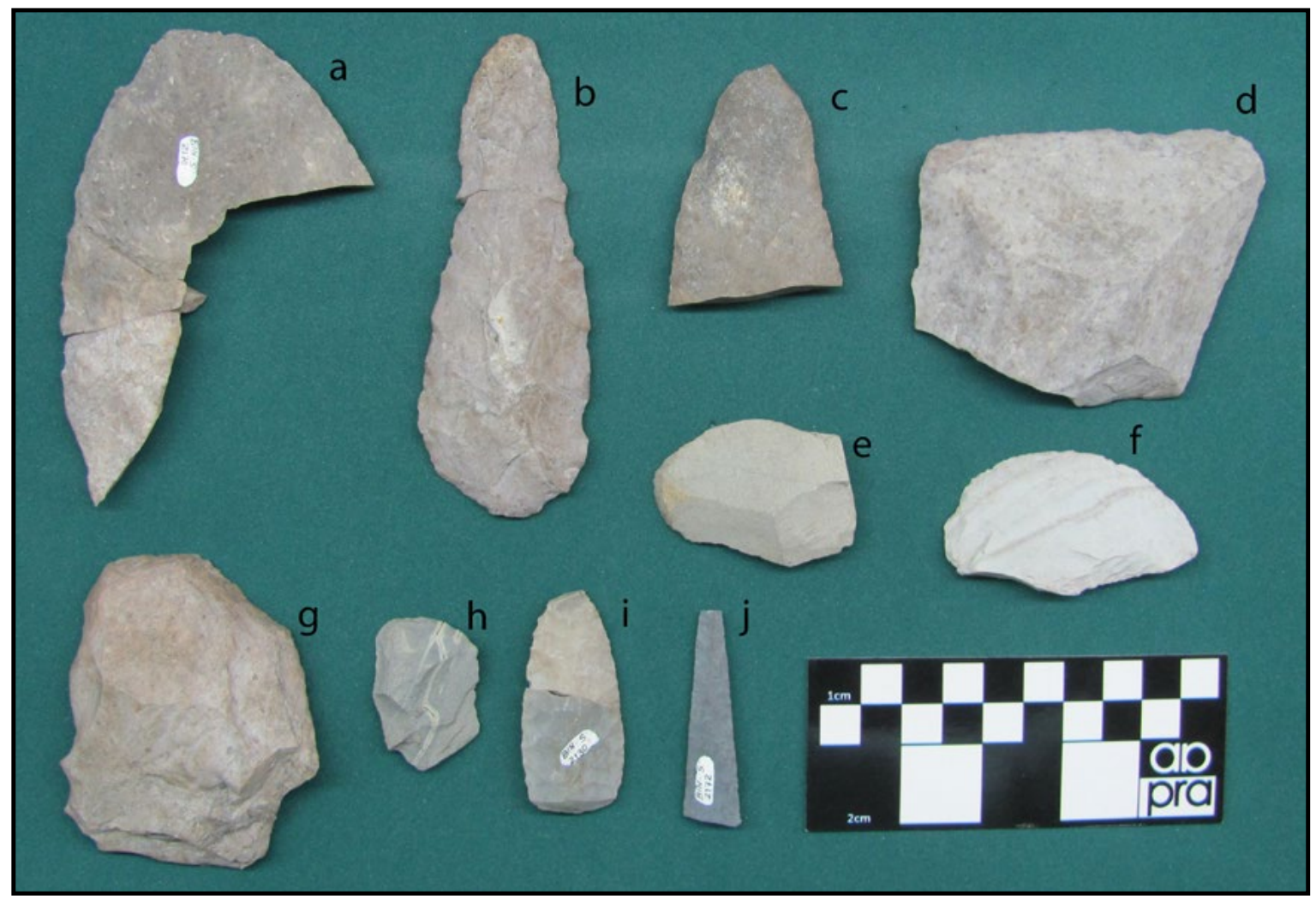

Figure 6. Lithic tools form layer S of Binushmuka I: blanks (a-c), side-scrapers (d-f), end-scrapers (g-h), and bifacial carving artifacts $(\mathrm{i}-\mathrm{j})$. 
Cores appear in both assemblages, while blanks are only presented in Area B. Blanks are bifaces of lanceolate shape and with an advanced lithic reduction. Tools include side-scrapers, end-scrapers and bifacial instruments (Figure 6). While the study of lithic raw materials is in process, the vast dominance of different types of rhyolites suggests a mostly local procurement.

Size sorting of the Binushmuka site has been analyzed from a quantitative framework based in scalar data representing frequencies of lithic artefacts. Visualization of site plans with color shading values depending on the frequency of lithic debris in layer $S$ (flakes and microflakes, separately) were done using ArcGIS 10.4 (Figure 7 and 9). Their values were transformed to percent values to combine them in a final representation of debitage concentration. From the comparison between both types of lithic debris, we assessed the degree of size sorting in the archaeological site.

The identification of statistically significant spatial hotspots which could be related to activity areas was performed using the autocorrelation statistical test Getis-Ord $\mathrm{Gi}^{*}$. In this analysis, the local sum for an entity and its neighbors is proportionally compared to the sum of all entities; when the local sum is different from expected, and that difference is too large to be the result of a random choice, a statistically significant $\mathrm{z}$ score is obtained. A positive $\mathrm{z}$ indicates higher autocorrelated values, always with low values of $\mathrm{p}$ (probability) indicating refusal of the null hypothesis of randomness (Getis \& Ord, 1992; Ord \& Getis, 1995). Getis-Ord Gi* values are displayed according to concentration zones of $99 \%, 95 \%$ and $90 \%$ of confidence level and areas without statistical significance (Figures 8 and 10). The degree of size sorting of the archaeological record can be assessed from the comparison between the hotspots by map algebra. Finally, lithic instruments, cores and blanks were added to the imagery output to assess the spatial correlation between them and the mentioned occupation areas.

As described above, although the evidence obtained in area $\mathrm{A}$ might be indicating reoccupations at longterm intervals of time, the integrity observed in the archaeological assemblages does not provide appro- priate criteria for assessing the spatial distribution of layer $\mathrm{C}$ at this location: part of the archaeological sequence of this area was affected by disturbance and removal of material, and the identification of burnt roots going through different layers raised uncertainties concerning radiocarbon data.

\section{Area A (Layer S)}

Frequencies of flakes $(\mathrm{N}=580)$ and microflakes $(\mathrm{N}=169)$ from layer $S$ were mapped in $0.5 \times 0.5 \mathrm{~m}$ quadrants (Figure 7), and no debris concentrations are clearly observed in Area A. However, the statistical analysis of the frequencies identifies spatial concentrations for both categories (Figure 8). Flakes are concentrated at the central part of the excavation. Microflakes appear with more density at the south section, but high densities also overlap with the concentration of flakes. The results show a low degree of size sorting. These concentrations of debitage are directly associated with tools and cores covering a surface of approximately $7 \mathrm{~m}^{2}$. As we have already mentioned above, prepared floors, post molds or hearth features were not recorded during the excavation in association with lithic assemblages.

\section{Area B (Layer S)}

In Figure 9 we present the frequencies for lithic debris mapped in $0.5 \times 0.5 \mathrm{~m}$ quadrants with 360 flakes and 7028 microflakes from layer S. Frequency distribution of flakes and microflakes show similar patterning: very low frequencies are presented in a wide space throughout the excavated area, while higher values result in a clear spatial patterning from the center to the southeast corner of the excavation. When densities are statistically analyzed and concentration zones are mapped (Figure 10), a high degree of size sorting becomes apparent. A dispersion of microflakes of approximately $7.5 \mathrm{~m}^{2}$ surrounding a hearth feature is identified. Concentrations of flakes also appear around of the hearth feature. It is remarkable that the concentration of the southeast corner has no significant representation of microflakes. Tools, blanks and cores appear along the periphery of the whole activity area, with the only exception of one blank. 


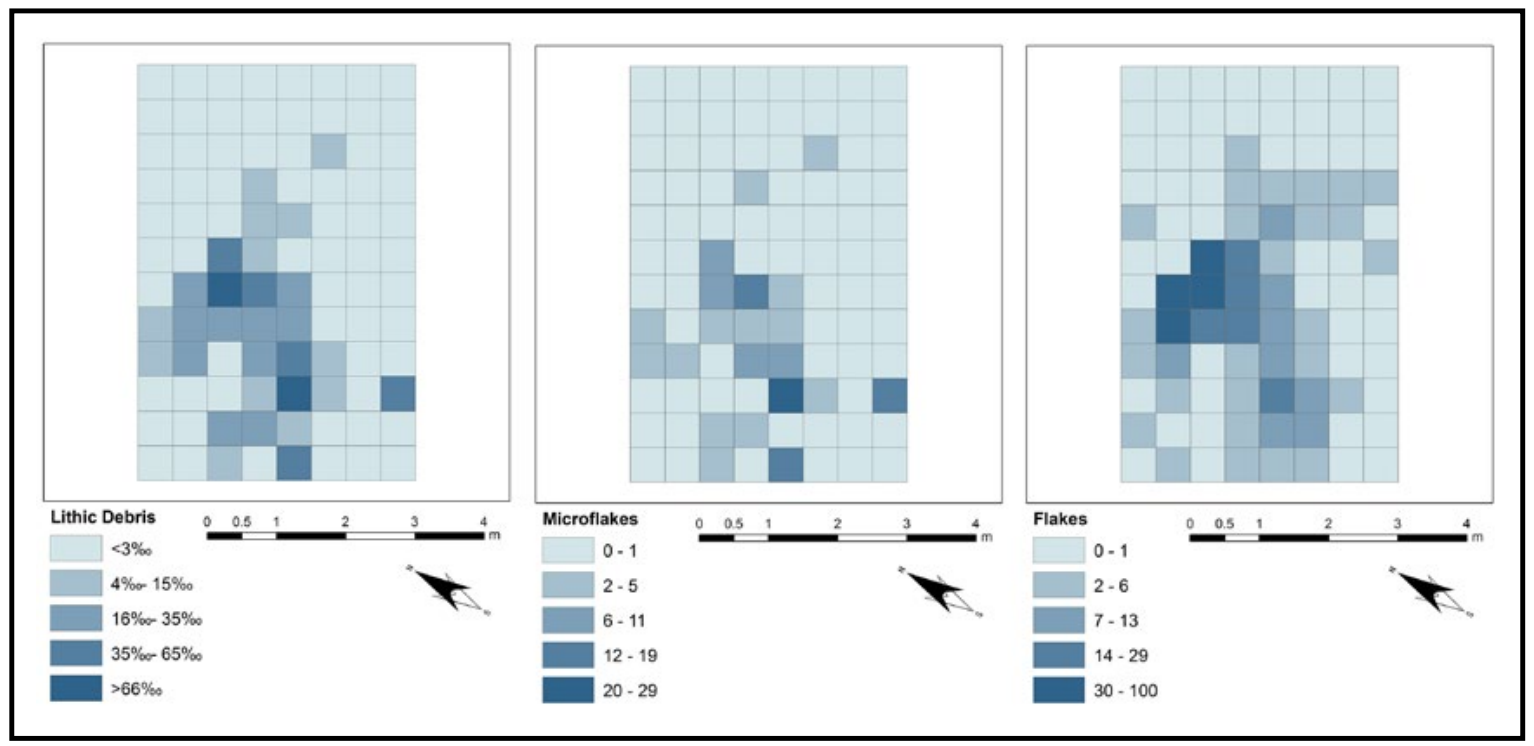

Figure 7. Percent distribution for layer $\mathrm{S}$ of lithic debris (flakes and microflakes combined) and absolute distributions of flakes and microflakes in Area A.

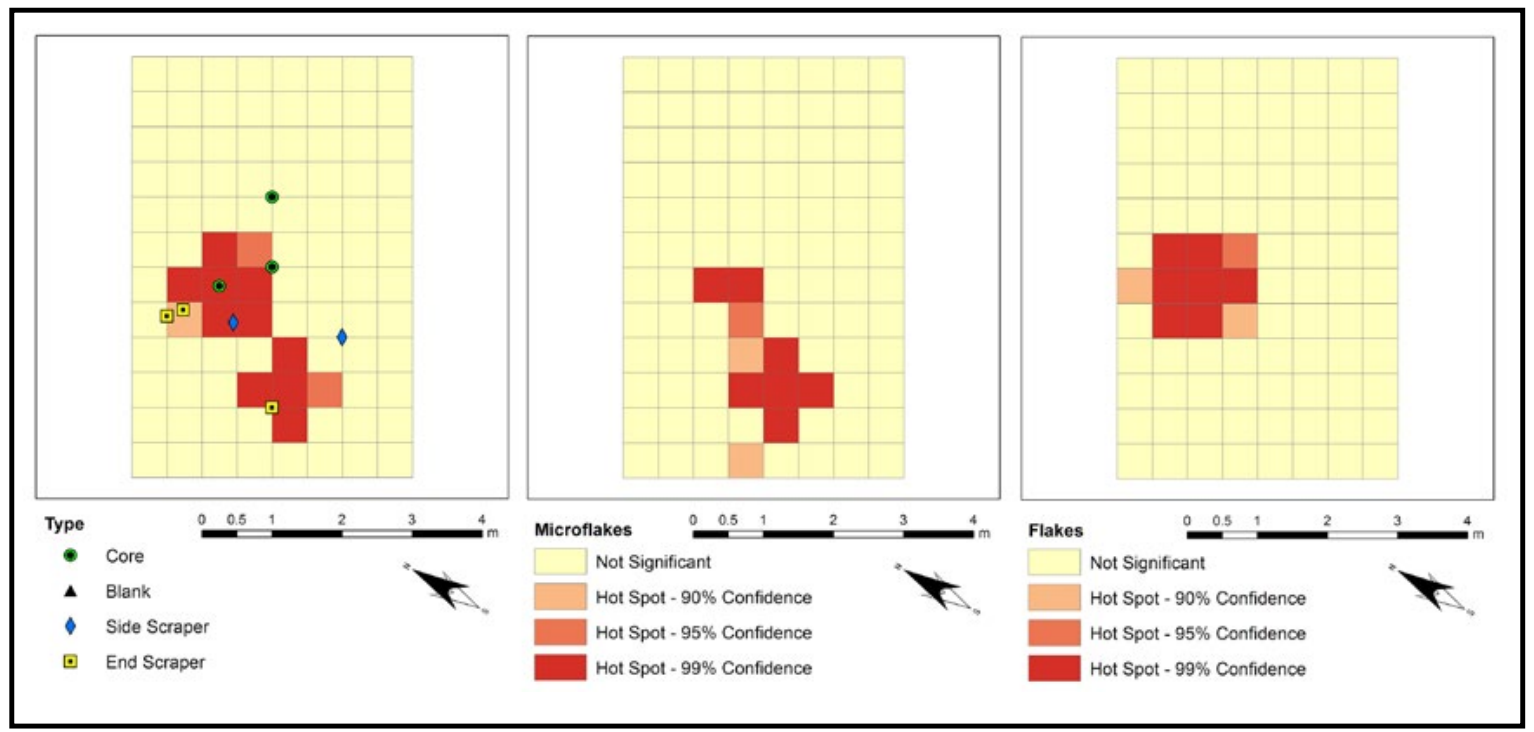

Figure 8. Hotspots for layer $\mathrm{S}$ by Getis-Ord Gi* for lithic debris (flakes and microflakes combined), flakes and microflakes in Area A.

\section{Area B (Layer C)}

Frequencies of flakes $(\mathrm{N}=679)$ and microflakes $(\mathrm{N}=486)$ from layer $\mathrm{C}$ were mapped by $0.5 \times 0.5 \mathrm{~m}$ quadrants (Figure 11): no debris concentrations are evident in Area B. Nevertheless, statistical analysis shows a spatial patterning in the distribution of lith- ic debris (Figure 12). Flakes are concentrated in two distinct sectors of the excavation, while microflakes are concentrated in the central part of the excavated area and detached from the former. These results show a low degree of size sorting. These concentrations of debitage are directly associated with tools and cores covering a surface of approximately $8 \mathrm{~m}^{2}$. 


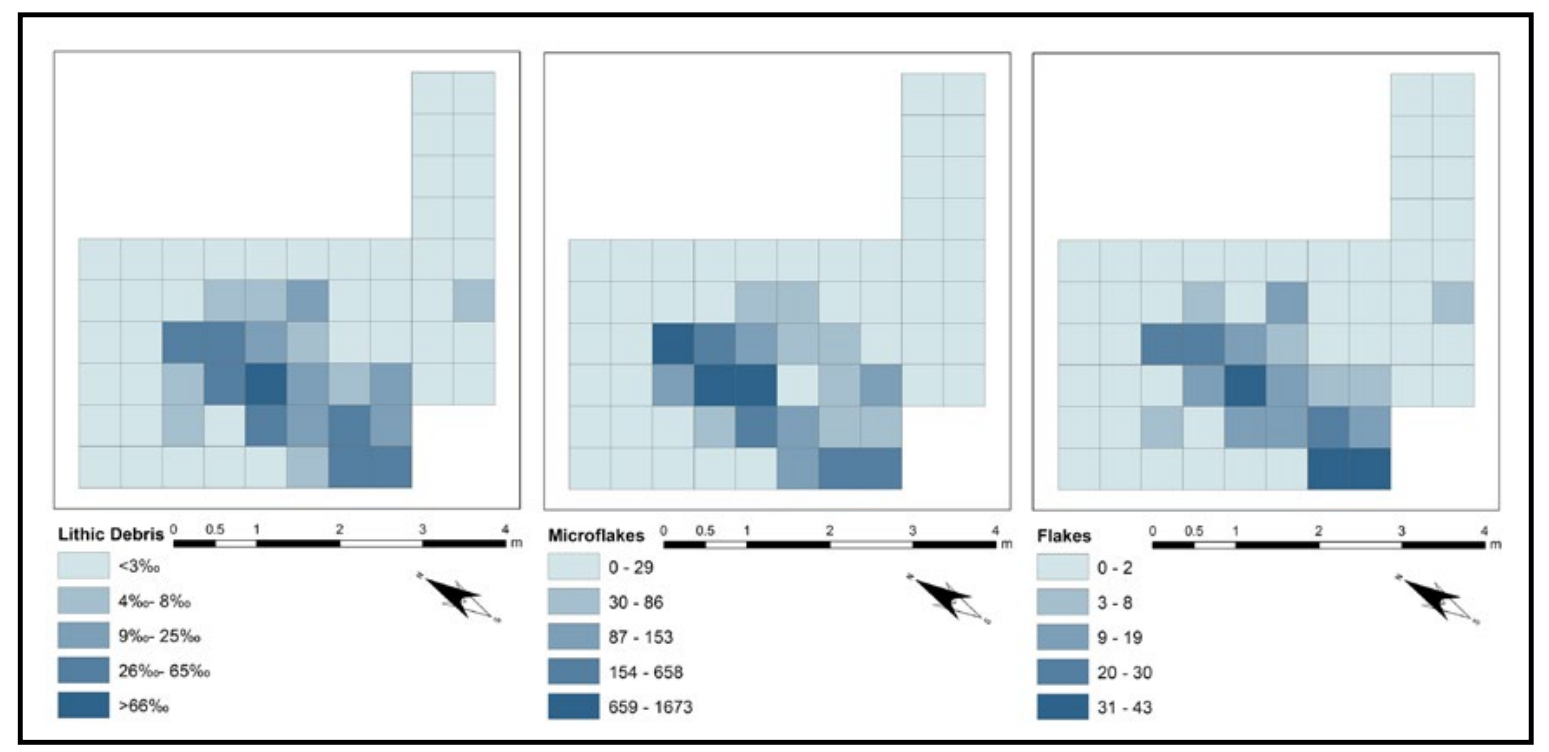

Figure 9. Percent distribution for layer $S$ of lithic debris (flakes and microflakes combined) and absolute distributions of flakes and microflakes in Area B.

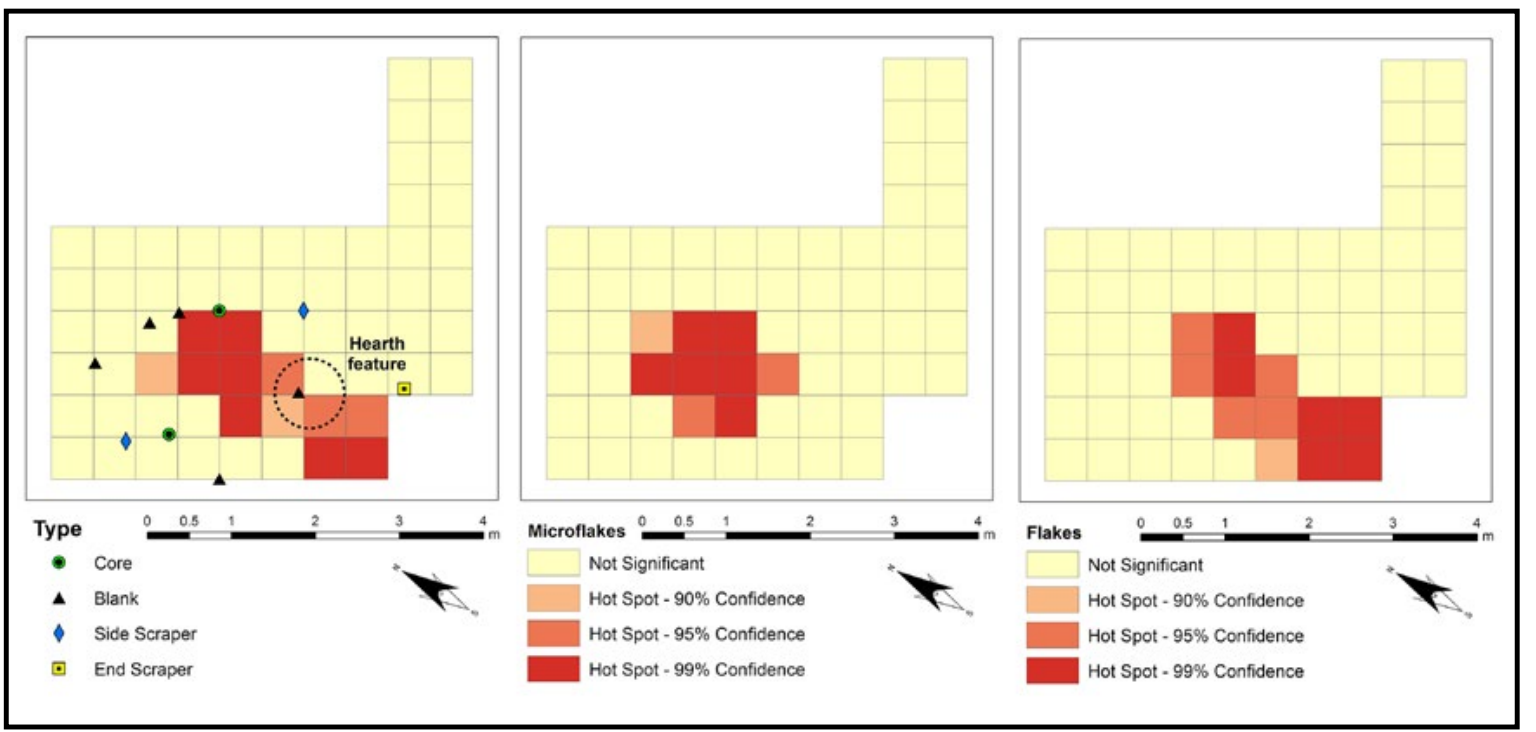

Figure 10. Hotspots for layer S by Getis-Ord Gi* for lithic debris (flakes and microflakes combined), flakes and microflakes in Area B. 


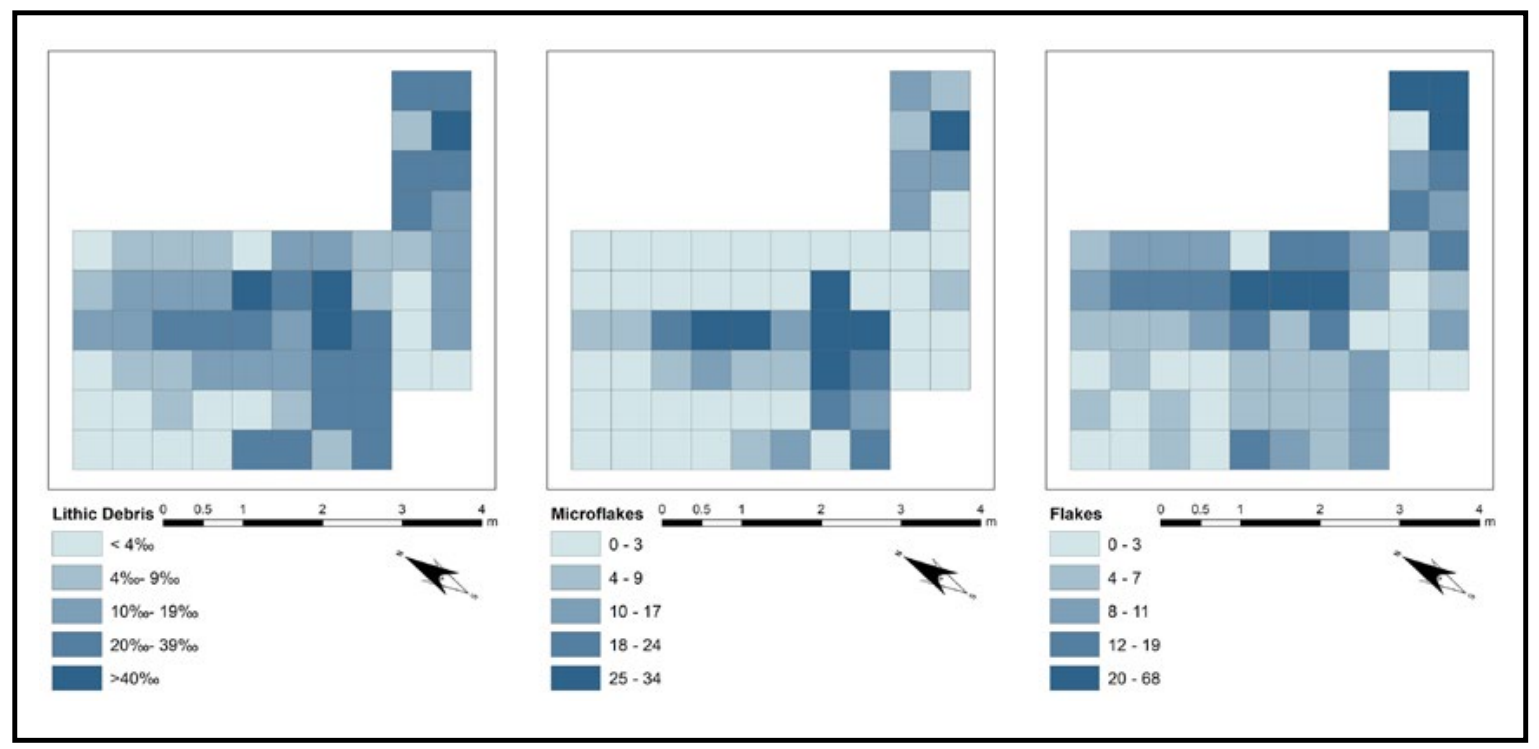

Figure 11. Percent distribution for layer $\mathrm{C}$ of lithic debris (flakes and microflakes combined) and absolute distributions of flakes and microflakes in Area B.

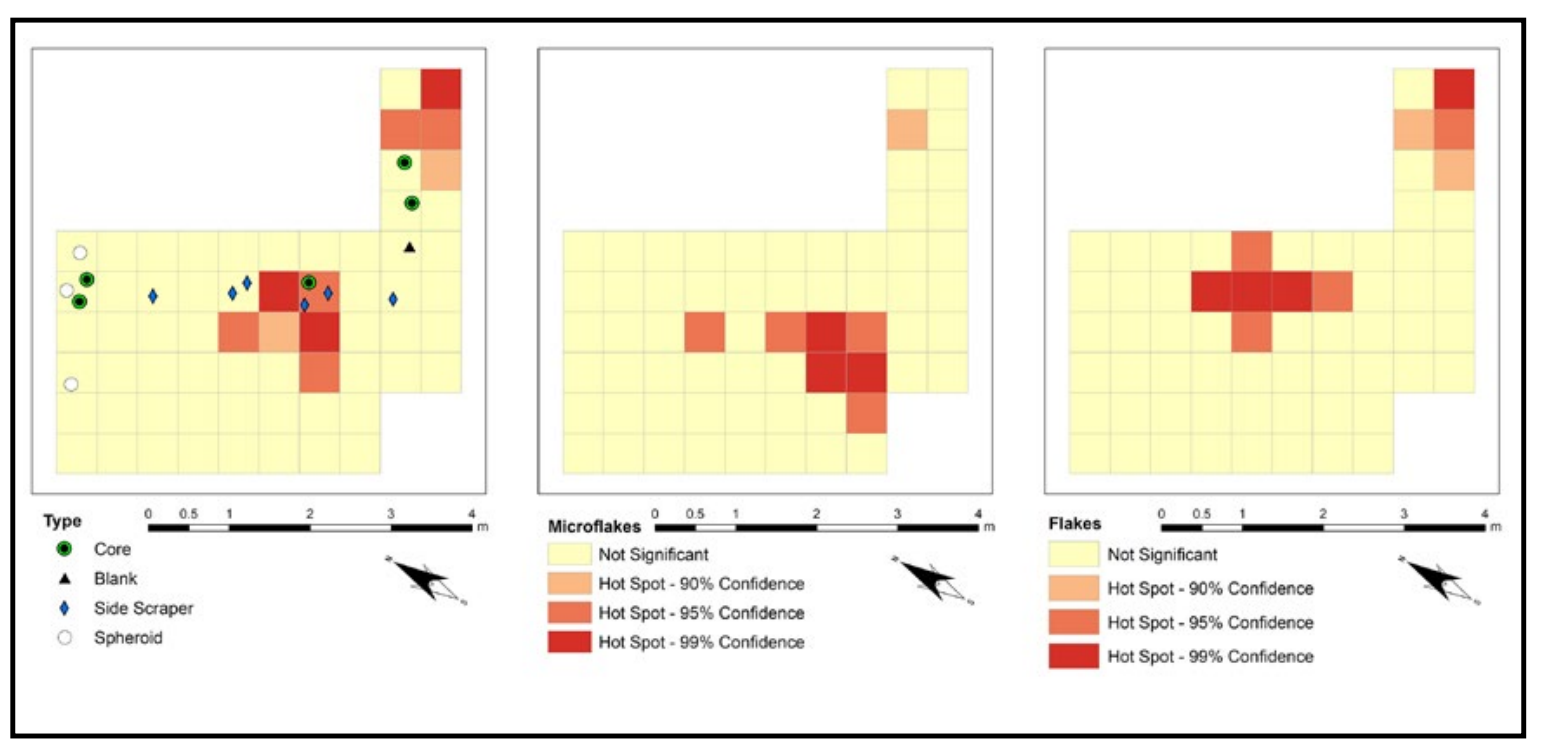

Figure 12. Hotspots for layer $\mathrm{C}$ by Getis-Ord Gi* for lithic debris (flakes and microflakes combined), flakes and microflakes in Area B. 


\section{Discussion}

The presented analyses allow us to make a series of observations on the temporal structure of the archaeological record of Binushmuka I. Occupations at layers $S$ and $C$ show similar spatial distribution of artifacts and features at the same locus, and lithic assemblages do not allow us to infer important differences in activities practiced at the site. Furthermore, the confined size of the assemblages $\left(-7-8 \mathrm{~m}^{2}\right)$ in both layers are likely to represent occupations by small sized groups. The archaeological discontinuity observed between layers $S$ and $C$, both in chronology and in accumulation of cultural material, is also a remarkable aspect in the temporal structure of the site.

Two other archaeological sequences including ECF components in the Beagle Channel region present a similar temporal structure to Binushmuka I. As it was mentioned in the introduction, the First Component of Túnel I, $6680 \pm 210$ and $6980 \pm 100 \mathrm{BP}$ (7590-7942 Cal. BP) (Orquera \& Piana, 1999), and the layer $S$ of Imiwaia I, $7842 \pm 53$ BP (8420-8662 Cal. BP) (Piana et al., 2012), appear as deposits with concentrations of lithic artifacts with poor organic preservation; there are only charcoal and a few bone fragments. ${ }^{7}$ Interestingly, Túnel I and Imiwaia I sites show shell midden formations from $6400 \mathrm{BP}$ to the late Holocene. Technological and zooarchaeological remains from those shell midden deposits provide evidence that marine foraging activities were developed (Orquera \& Piana, 1999; Schiavini, 1993; Zangrando, 2009). Furthermore, the presence of green obsidian artefacts in shell middens at both sites was interpreted as supporting social networks between the Beagle Channel and Brunswick Peninsula as maritime trade routes (Alvarez 2004, Morello et al., 2012). Additionally, the sizes of the occupied areas registered in EFC assemblages are no different to those presented by shell midden formation stud-

7 Although the poor bone preservation means a disadvantage for understanding the relation between humans and the marine environment, the few pinniped remains recovered in the First Component of Túnel I indicate an interaction with the marine environment with significant implications for the colonization of seascapes (see Bjerck, Breivik, Piana \& Zangrando, 2016a). ies for marine foragers (Piana \& Orquera, 2010), which were characterized as small social groups with high mobility patterns. No shell midden formation was observed in Binushmuka, however the spatial patterning and the resulting overlapping between occupations of the early and middle Holocene, and the technological composition including the use of green obsidian in occupations of the middle Holocene show similar trajectories through time in the site-use in all three cases.

Why do we observe a repetitive spatial pattern in site locations between the early and the middle Holocene? The location of dwelling places is not a random phenomenon. Among other factors, it depends on mobility strategies and social organization demands on geographical conditions and features of the environment, and how that features are socially reproduced (Hayden, 1979; Schlanger, 1992; Politis, 1996). As a corollary, the answer should depend to some degree on visible traces in the landscape. Rock-shelters are a classic example as repeated dwelling places over long periods of time due to the fact that they are visible and accessible features in the landscape that can provide refuge to many generations of people and/or to different societies at different times (Bailey \& Galanidou, 2009). Open site formations such as shell middens can have a similar effect, where the conscious or unconscious rapid accumulations of discarded materials create features in the landscape that attract re-use because of different reasons (Bailey, 1977; Piana \& Orquera, 2010). The dwelling structures (e.g., wood huts) can also invoke re-occupations for many hunter-gatherer societies (Piana \& Orquera, 2010), but due to the durability of building materials it is not expected that it works as a visible trace after long periods of abandonment. None of these possibilities are however applicable to the earliest occupations of the Beagle Channel. On one hand, the ECF assemblages appear as archaeological deposits that were rapidly buried, and it is unlikely that they provided any persistent surface phenomena in the past (e.g., shell midden). On the other hand, the chronological differences between those earlier occupations and the subsequent uses of the sites generate discontinuities of several centuries and even more than a millennium which makes it difficult to think about the reuse of preexistent dwelling structures. 


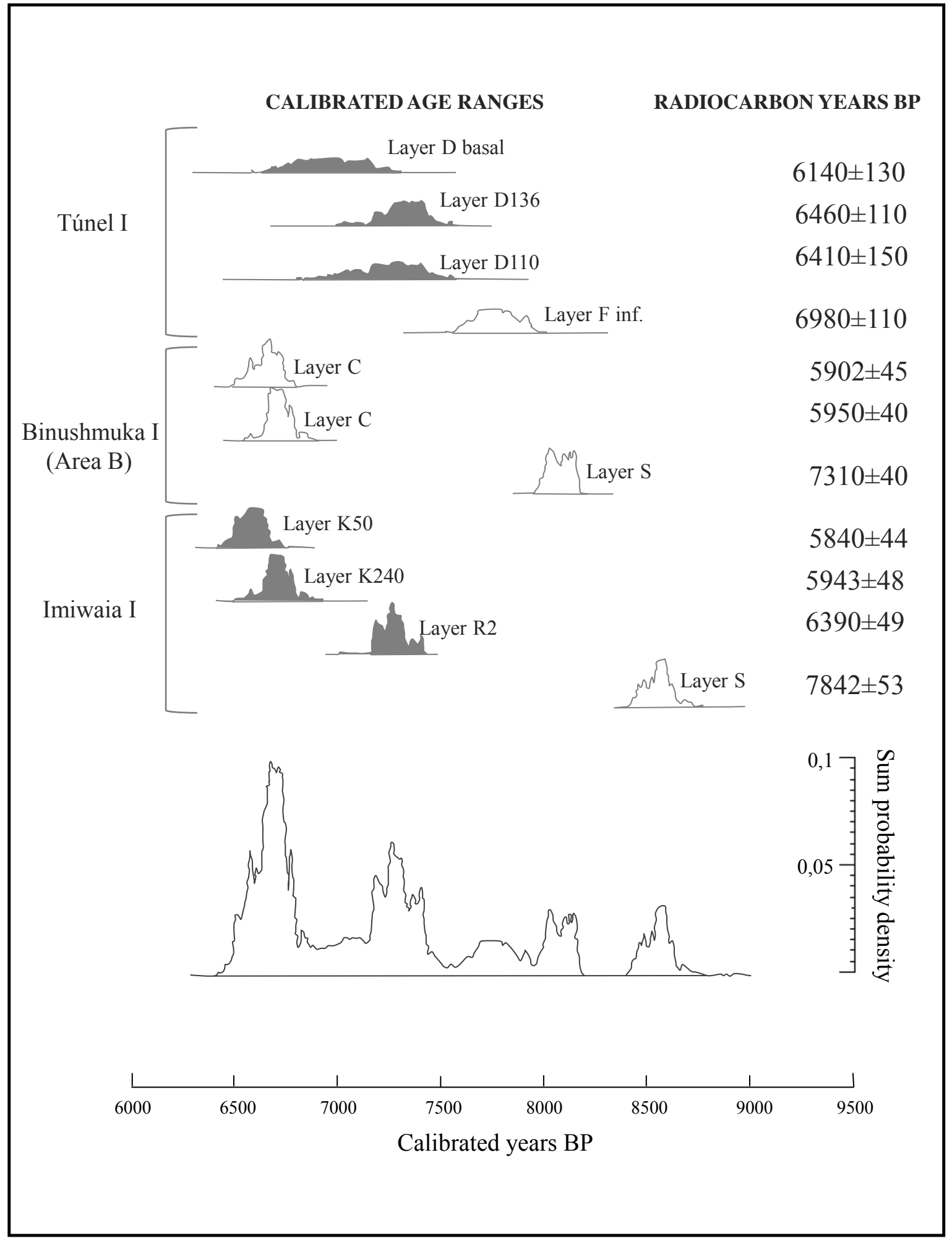

Figure 13. Calibrated age ranges and sum probabilities from early and middle Holocene deposits of Túnel I, Binushmuka I and Imiwaia I sites. Radiocarbon ages (Orquera \& Piana, 1999; Zangrando, 2009) were calibrated with Calib 6.0 (22-SHCal04) (McCormac et al., 2004). Grey ranges indicate shell midden formations. 
Features of the topography may have unique qualities that make them especially suited for certain practices and behaviours (Schlanger, 1992). In this sense, distinctive features in the landscape would have also worked as visible traces during long time periods indicating good settlement conditions and prompted to the re-use of specific places. If we look closely, the location of Binushmuka in relation to the landforms at Figure 2, it is possible to observe that this site is circumscribed to coastal landforms. Systematic test-pit surveys and radiocarbon analysis performed by the authors in the area and on different landforms nearby Binushmuka did not provide evidence of further occupations of the early Holocene (Bjerck et al., 2016b). This suggests that different landscape features resulted in the selection of different dwelling places. Therefore, the spatial consistency between early and middle Holocene occupations makes it difficult to assume that the repeated use of specific locations was a fortuitous factor. Rather, it is more reasonable to assume that groups with similar mobility patterns and foraging strategies used those locations.

Archaeological discontinuities of different magnitudes were recorded between earlier occupations at Imiwaia I, Binushmuka I, and Túnel I sites. In the first two cases the hiatus between layers $S$ and the subsequent occupations are approximately 1400 years, while in Túnel I the difference between the First Component and the shell midden formation is nearly 500 years. However, when radiocarbon data is calibrated and plotted as sum probabilities to obtain a regional view, the distribution shows continuity between occupations of the early Holocene and those of the mid-Holocene, with a short hiatus between 8400-8200 cal. BP (Figure 13). Thus, the lack of site-use at particular locations and during specific time periods does not mean there is an archaeological discontinuity at a regional scale.

\section{Conclusion}

Previous evaluations on technological assemblages from basal deposits of Túnel I and Imiwaia I stated that first human occupations in the Beagle Channel corresponded to inland hunter-gatherer groups (Orquera \& Piana, 2009). This produces a logical conclusion of discontinuity between those populations and the hunter-gatherers with technological capabilities for foraging in the sea which colonized the region in the mid-Holocene. The spatio-temporal analysis developed in this work, first assessing the Binushmuka I case and then establishing comparisons with the other two early contexts known for the region, does not support the existence of discontinuity between early and middle Holocene occupations, either in the location of sites or in the historical timeline at a regional scale. The discontinuity seems to be exclusively marked by typological criteria. While the spatial consistency observed among early occupations on the Beagle Channel region should not be considered as a determining factor to support the presence of marine foragers from the early Holocene, it does promote new considerations addressing the peopling of the archipelago at the southern tip of South America.

\section{Acknowledgments}

This research was supported by the following projects: PIP0387 (CONICET- dir. Atilio Francisco Zangrando and Ernesto L. Piana) and the "Marine Ventures" Project (Research Council of Norway - no 208828 - dir. Hein Bjerck). The following persons have collaborated in fieldwork: Daniela Alunni, Julieta Angel, Danae Fiore, Ernesto Gonet, Magnhild M. Husøy, María Paz Martinoli, Karen Ørbog Oftedal, Germán Pinto Vargas, Andrés Robledo, Birgitte Skar, Lucas Sosa, and Elisabeth Swensen. Germán Pinto Vargas has prepared the archaeological material for its study at the lab.

\section{References}

Alvarez, M. R. (2004). Estrategias tecnológicas en los grupos canoeros tempranos del área fuegopatagónica. Magallania, 32, 191-208.

Ames, K.M. (2002). Going by Boat. In Fitzhugh, B. and Habu, J. (Eds). Beyond Foraging and Collecting. Fundamental Issues in Archaeology (pp. 19-52). Boston: Springer.

Bailey, G. N. (1977). Shell mounds, shell middens and raised beaches in the Cape York Peninsula. Mankind, 11, 132-143. 
Bailey, G. N. (2008). Time perspectivism: origins and consequences. In Holdaway, S. and Wandsnider, L. (Eds.). Time in archaeology: Time Perspectivism Revised (pp. 1330). Utah: Utah University Press.

Bailey, G. N. \& Galanidou, N. (2009). Caves, palimpsests and dwelling spaces: examples from the Upper Palaeolithic of south-east Europe. World Archaeology, 41, 215-241.

Bailey, G. N. \& Milner, N. (2002). Coastal hunter-gatherers and social evolution marginal or central? Before Farming, 3-4, 1-22.

Bartram, L. E., Kroll, E. M. \& Bunn, H. T. (1991). Variability in Camp Structure and Bone Food Refuse Patterning at Kua San Hunter-Gatherer Camps. In Kroll, E. M. \& Price, T. D. (Eds.). The Interpretation of Archaeological Spatial Patterning (pp. 77-147). New York: Springer.

Binford, L. R. (1978). Dimensional analysis of behavior and site structure: learning from an Eskimo hunting stand. American Antiquity, 43, 330-361.

Binford, L. R. (1983). In pursuit of the past. Decoding the Archaeological Record. New York: Thames and Hudson.

Bjerck, H. B. (1990). Mesolithic site types and settlement patterns at Vega, Northern Norway. Acta Archaeologica, 60, 1-32.

Bjerck, H. B. (2009). Colonizing Seascapes: Comparative Perspectives on the Development of Maritime Relations in Scandinavia and Patagonia. Arctic Anthropology, 46, 118-131.

Bjerck, H. B. (2017). Settlements and Seafaring: Reflections on the Integration of Boats and Settlements Among Marine Foragers in Early Mesolithic Norway and the Yámana of Tierra del Fuego. The Journal of Island and Coastal Archaeology, 12, 276-299

Bjerck, H. B., Breivik, H. M., Piana, E. L. \& Zangrando, A. F. (2016a). Exploring the role of pinnipeds in the human colonization of the seascapes of Patagonia and Scandinavia. In Bjerck, H. B., Breivik, H. M., Fretheim, S. E., Piana, E. L., Skar, B., Tivoli, A. M. and Zangrando, A. F. J. (Eds.). Marine Ventures. Archaeological Perspectives on Human-Sea Relations (pp. 53-73). Sheffield: Equinox.
Bjerck, H. B., Zangrando, A. F., Breivik, H. M., Piana, E. L. \& Negre, J. (2016b). Marine Ventures: The Cambaceres surveys (2009, 2011-2013). NTNU Vitenskapsmuseet arkeologisk rapport http://www.ntnu.no/vitenskapsmuseet/publikasjoner

Bjerck, H. B. \& Zangrando, A. F. (2016). Introduction: Marine Ventures-archaeological perspectives on human-sea relations. In Bjerck, H. B., Breivik, H. M., Fretheim, S. E., Piana, E. L., Skar, B., Tivoli, A. M. and Zangrando, A. F. J. (Eds.). Marine Ventures. Archaeological Perspectives on Human-Sea Relations (pp. 5-14). Sheffield: Equinox.

Breivik, H. M., Bjerck, H. B, Zangrando, A. F. \& Piana, E. L. (2016). Exploring the applicability of environmental and ethnographic reference frames in high-latitude seascapes: Mobility patterns among the marine foragers of Norway and Tierra del Fuego. In Bjerck, H. B., Breivik, H. M., Fretheim, S. E., Piana, E. L., Skar, B., Tivoli, A. M. and Zangrando, A. F. J. (Eds.). Marine Ventures. Archaeological Perspectives on Human-Sea Relations (pp. 75-94). Sheffield: Equinox.

Brooks, A. \& Yellen, J. E. (1987). The Preservation of Activity Areas in the Archaeological Record: Ethnoarchaeological and Archaeological Work in Northwest Ngamiland, Botswana. In Kent, S. (Ed.). Method and Theory for Activity Area Research: An Ethnoarchaeological Approach (pp. 63-106). New York: Columbia University Press.

Bujalesky, G. (2011). The Flood of the Beagle Channel (11,000 YR B.P.), Tierra del Fuego. Anales del Instituto de la Patagonia, 39(1), 5-21.

Chatters, J. (1897). Hunter-gatherer adaptations and assemblage structure. Journal of Anthropological Archaeolo$g y, 6,336-375$.

Clark, A. E. (2016). Time and space in the Middle Paleolithic: Spatial structure and occupation dynamics of seven open-air sites. Evolutionary Anthropology, 25, 153163.

Codding, B. F., Zeanah, D. W., Bliege Bird, R., Parker, C. H., \& Bird, D. W. (2016). Martu ethnoarchaeology: Foraging ecology and the marginal value of site structure. Journal of Anthropological Archaeology, 44, 166-176. 
Erlandson, J. M. (2001). The Archaeology of Aquatic Adaptations: Paradigms for a New Millennium. Journal of Archaeological Research, 9, 287-350.

Farr, T. G., Rosen, P. A., Caro, E., Crippen, R., Duren, R., Hensley, S., Kobrick, M., Paller, M., Rodriguez, E., Roth, L., Seal, D., Shaffer, S., Shimada, J., Umland, J., Werner, M., Oskin, M., Burbank, D., Alsdorf, D. (2007). The Shuttle Radar Topography Mission. Reviews of Geophysics, 45, 1-3. DOI:10.1029/2005RG000183

Getis, A. \& Ord, J. K. (1992). The Analysis of Spatial Association by Use of Distance Statistics. Geographical Analysis, 24(3), 189-206.

Gordillo, S., Bujalesky, G., Pirazzoli, A., Rabassa, J. \& Saliège, J. F. (1992). Holocene raised beaches along the northern coast of the Beagle Channel, Tierra del Fuego, Argentina. Palaeogeography, Palaeoclimatology and Palaeoecology, 99, 41-54.

Grill, S., Borromei, A., Quattrocchio, M., Coronato, A., Bujalesky, G. \& Rabassa, J. (2002). Palynological and sedimentological analysis of Holocene sediments from Río Varela, Beagle Channel, Tierra del Fuego, Argentina. Revista Española de Micropaleontología, 34, 145- 161.

Hayden, B. (1979). Palaeolithic Reflections: Lithic Technology and Ethnographic Excavations among Australian Aborigines. Canberra: Australian Institute of Aboriginal Studies.

Hitchcock, R. K. (1987). Sedentism and Site Structure: Organizational Changes in Kalahari Barsawa Residential Locations. In Kent, S. (Ed.). Method and Theory for Activity Area Research: An Ethnoarchaeological Approach (pp. 374-423). New York: Columbia University Press.

Isla, F. I. \& Bujalesky, G. (2008). Coastal geology and morphology of Patagonia and Fueguian Archipielago. In Rabassa, J. (Ed.). The Late Cenozoic of Patagonia and Tierra del Fuego (pp. 227-240). Philadelphia: Elsevier.

Lyman, R. L. (1991). Prehistory of the Oregon Coast. The Effects of Excavation Strategies and Assemblage Size on Archaeological Inquiry. San Diego, CA: Academic Press.

Mccormac, F. G., Hogg, A. G, Blackwell, P. G., Buck, C. E., Higham, T. F. G. \& Reimer, P. J. (2004). SHCal04 Southern Hemisphere Calibration 0-11 cal kyr BP. Radiocarbon, 46, 1087-1092.
Morello, F., Borrero, L., Massone, M., Stern, Ch., GarcíaHerbst, A., McCulloch, R., Arroyo-Kalin, M., Calás, E., Torres, J., Prieto, A., Martínez, I., Bahamonde, G. \& Cárdenas, P. (2012). Hunter-gatherers, biogeographic barriers and the development of human settlement in Tierra del Fuego. Antiquity, 86, 71-87.

O'Connell, J. F. (1987). Alyawara site structure and its archaeological implications. American Antiquity, 52, 74-108.

Ord, J. K. \& Getis, A. (1995). Local Spatial Autocorrelation Statistics: Distributional Issues and an Application. Geographical Analysis, 27(4), 286-306.

Orquera, L. A. \& Piana, E. L. (1999). Arqueología de la región del canal Beagle (Tierra del Fuego, República Argentina). Buenos Aires: Sociedad Argentina de Antropología.

Orquera, L. A. \& Piana, E. L. (2009). Sea Nomads of the Beagle Channel in Southernmost South America: Over Six Thousand Years of Coastal Adaptation and Stability. Journal of Island \& Coastal Archaeology, 4, 61-81

Piana, E. L. \& Orquera, L. A. (2010). Shellmidden formation at the Beagle Channel (Tierra del Fuego, Argentina). In Calado, D., Baldia, M. \& Boulanger, M. (Eds.). Monumental questions: Prehistoric megaliths, Mounds and Enclouses (pp. 263-271). Oxford: BAR International Series 2122 .

Piana, E. L., Zangrando, A. F. \& Orquera, L. A. (2012). Early occupations in Tierra del Fuego and the evidences from $S$ layer in Imiwaia I site (Beagle Channel, Argentina). Current Research in the Pleistocene, Center for the Study of First American. Southbound. Late Pleistocene Peopling of Latin America (Special edition), 171-175.

Politis, G., (1996). Moving to produce: Nukak mobility and settlement patterns in Amazonia. World Archaeology, 27, 492-511.

Rabassa, J., Heusser, C. \& Stuckenrath, R. (1986). New data on Holocene sea transgressión in the Beagle Channel (Tierra del Fuego). Quaternary of South America and Antarctic Peninsula, 4, 291-309.

Rabassa, J., Heusser, C. \& Rutter, N. (1990). Late glacial and Holocene sea transgression in the Beagle Channel (Tierra del Fuego). Quaternary of South America and Antarctic Peninsula, 7, 335-360. 
Rabassa, J., Coronato, A., Gordillo, S., Candel, M. S. \& Martinez, M. (2009). Paleoambientes litorales durante el inicio de la transgresión marina holocena en bahía Lapataia, Canal Beagle, Parque Nacional Tierra del Fuego. Revista de la Asociación Geológica Argentina, 65(4), 648-659.

Schiavini, A. M. (1993). Los lobos marinos como recurso para cazadores-recolectores marinos: el caso de Tierra del Fuego. Latin American Antiquity, 4, 346-366.

Schlanger, S. H. (1992). Recognizing persistent places in Anasazi settlement systems. In Rossignol, J. and Wandsnider, L. (Eds.). Space, Time, and Archaeological Landscapes (pp. 91-112). New York: Plenum Press.

Stevenson, M. G. (1991). Beyond the Formation of HearthAssociated Artifact Assemblages. In Kroll, E. M. and
Price, T. D. (Eds.). The Interpretation of Archaeological Spatial Patterning (pp. 269-299). New York: Springer.

Yesner, D. (1980). Maritime hunter-gatherers: ecology and prehistory. Current Anthropology, 21, 727-750.

Zangrando, A. F. (2009). Historia evolutiva y subsistencia de cazadores-recolectores marítimos de Tierra del Fuego. Colección Tesis de Doctorado. Buenos Aires: Sociedad Argentina de Antropología.

Zangrando, A. F., Ponce, J. F., Martinoli, M. P., Montes, A., Piana, E. \& Vanella, F. (2016). Paleogeographic changes drove prehistoric fishing practices in the Cambaceres Bay (Tierra del Fuego, Argentina) during the middle and late Holocene. Environmental Archaeology: The Journal of Human Paleoecology, 21, 182-192. 